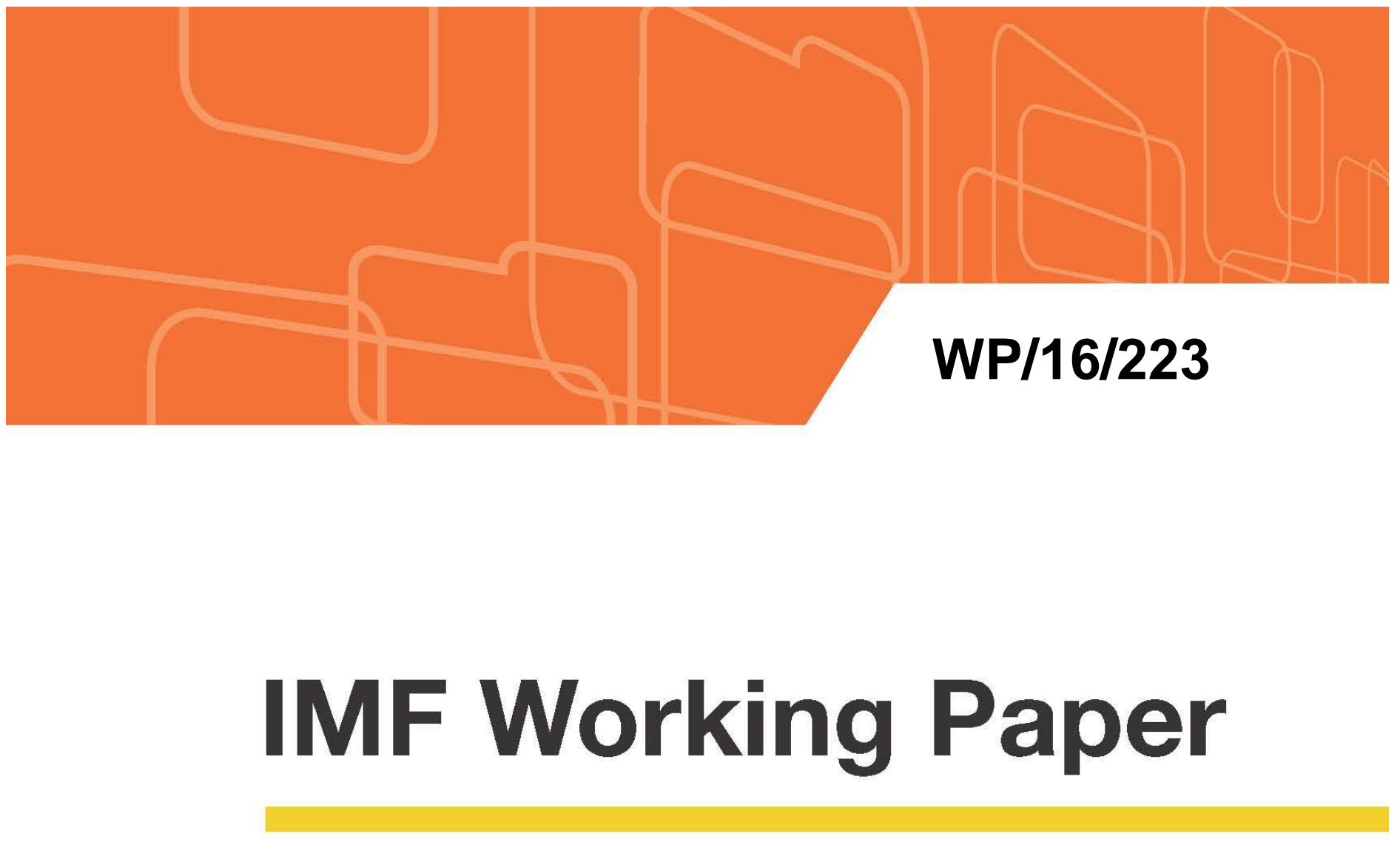

\title{
Stock Market Liquidity in Chile
}

By Luis Brandao-Marques

IMF Working Papers describe research in progress by the author(s) and are published to elicit comments and to encourage debate. The views expressed in IMF Working Papers are those of the author(s) and do not necessarily represent the views of the IMF, its Executive Board, or IMF management. 


\title{
IMF Working Paper
}

Western Hemisphere Department

Stock Market Liquidity in Chile

Prepared by Luis Brandao-Marques

Authorized for distribution by Stephan Danninger

November 2016

IMF Working Papers describe research in progress by the author(s) and are published to elicit comments and to encourage debate. The views expressed in IMF Working Papers are those of the author(s) and do not necessarily represent the views of the IMF, its Executive Board, or IMF management.

\begin{abstract}
Chile has a large but relatively illiquid stock market. Global factors such as global risk appetite and monetary policy in advanced economies are key cyclical determinants of liquidity in Chilean equities. Evidence from a cross-section of emerging markets suggests strong protection of minority shareholders can help improve stock market liquitidity. Currently, illiquid in Chilean may have to pay $3 \frac{1}{2}$ percent more as cost of equity. Corporate governance should be improved, namely through the adoption of a stewardship code.
\end{abstract}

JEL Classification Numbers: G12; G15; G23; G34

Keywords: Market liquidity; investor protection; corporate governance; liquidity premium. Author's E-Mail Address: lmarques@imf.org 


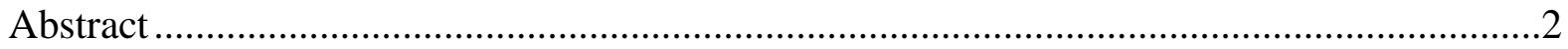

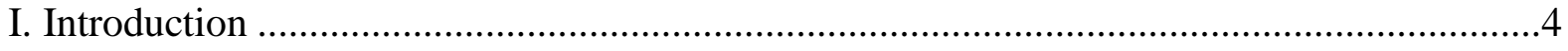

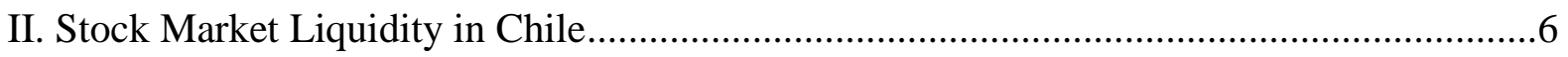

III. Determinants of Market Liquidity for Chilean Stocks ........................................................

A. Moving from high to low liquidity: The role of cyclical factors ..............................

B. What explains liquidity? A cross-country regression ............................................11

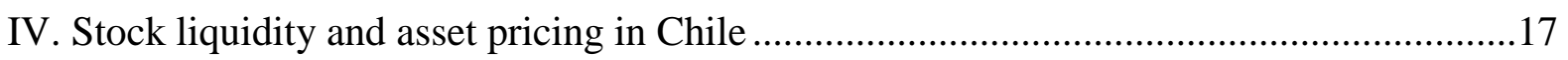

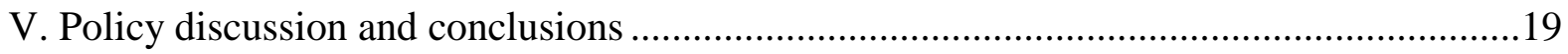

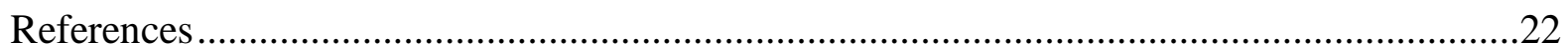

Tables

Table 1. Liquidity Regimes in the Chilean Stock Market ……………................................10

Table 2. Market Liquidity, Ownership Concentration, and Shareholder Protection ................14

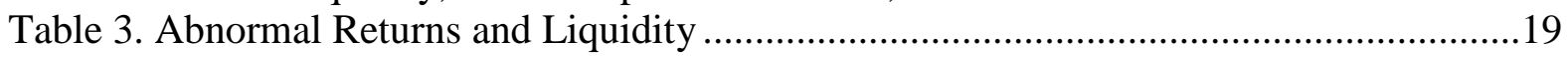

Figures

Figure 1. Turnover and Quoted Spreads .............................................................................

Figure 2. Aggregate Liquidity in Chilean Stocks ..............................................................

Figure 3. Market Liquidity for Institutional Investors (2010-2013) ......................................

Figure 4. Stock Market Liquidity Regimes in Chile ...............................................................

Boxes

Box 1. Why Does Liquidity in the Stock Market Matter? .........................................................

Box 2. Shareholder Protection, Corporate Governance, and Market Liquidity........................15

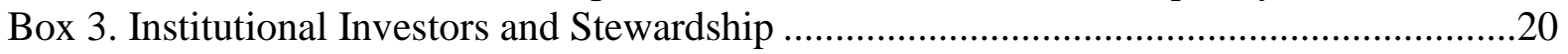

Appendixes

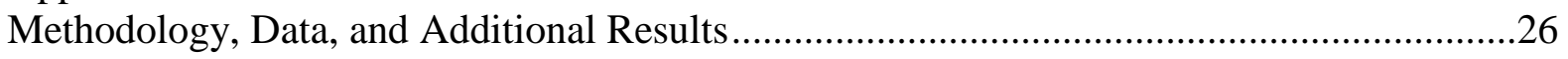

Appendix Tables

Appendix Table 1. Descriptive Statistics for Emerging Market Panel Study..........................28 


\section{INTRODUCTION}

1. Liquidity in Chile's stock market is relatively low compared to other economies. Chile has a large stock market in terms of market capitalization to GDP when compared to other OECD countries but does not rank high in terms of market liquidity (see Amihud, Hameed, Kang, and Zhang, 2015). Stock market liquidity in Chile has, in the past, been closely associated with domestic economic developments. However, in the past five years, stock market turnover has declined and bid-ask spreads have risen somewhat (Figure 1).

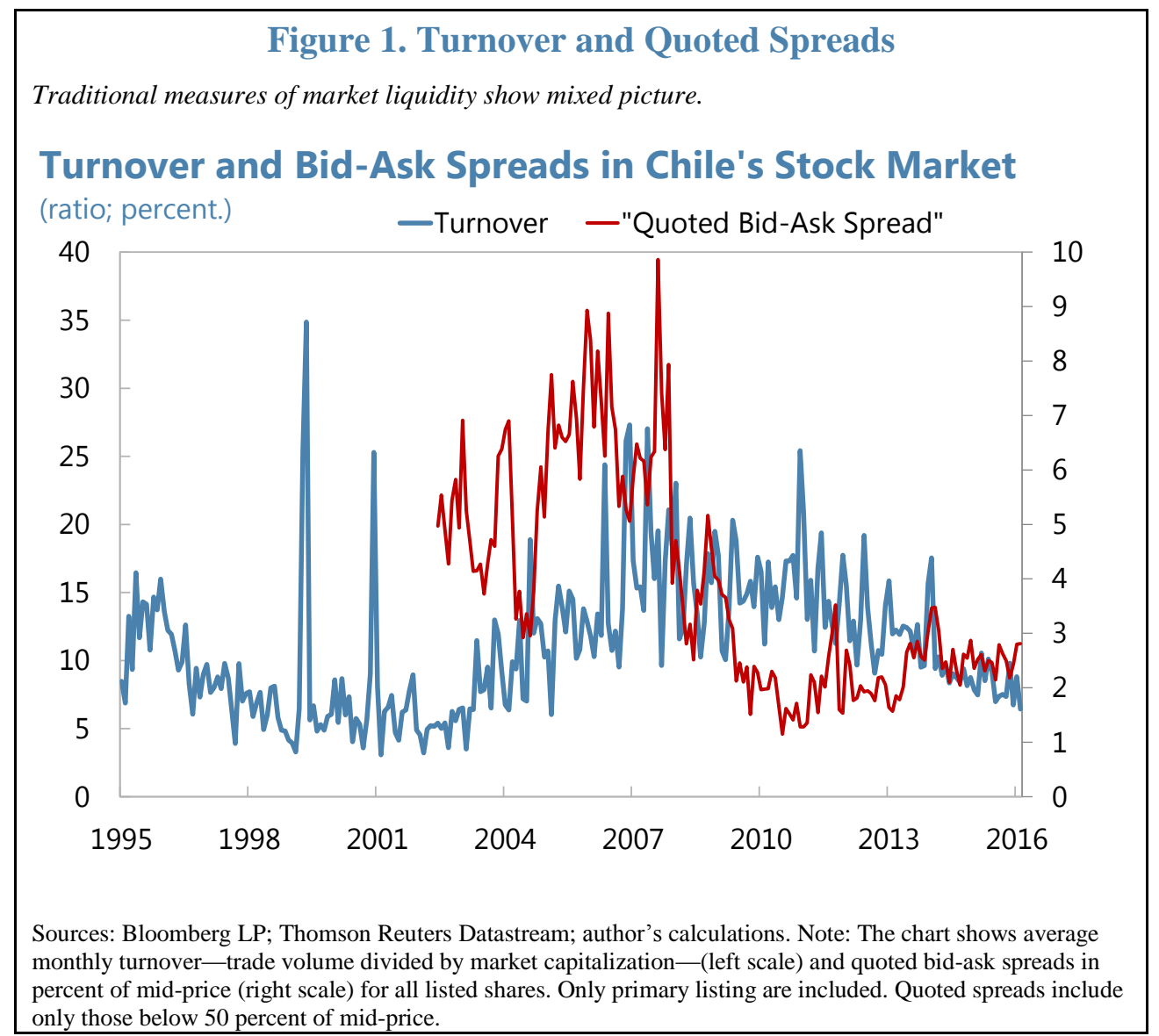

2. Low stock market liquidity has important economic consequences (Box 1). In particular, illiquid stock markets may drive up the cost of equity, possibly depressing business investment and economic activity. Low liquidity in the stock market is also associated with higher corporate indebtedness and lower growth opportunities for startups and SMEs. Finally, low market liquidity is associated with more frequent mispricing of assets, which can lead to asset price bubbles, misallocation of capital, and financial fragility. 
3. In order to assess the trends and costs of stock market illiquidity in Chile and exploit some of its possible structural determinants, the paper uses three separate empirical strategies. First, to assess the influence of cyclical conditions on stock market liquidity and its resilience, this study uses a regime-switching regression approach to determine the unobservable state of liquidity and then relates it to cyclical drivers (see IMF 2015). Second, using a sample of 23 emerging market economies, the paper relies on a country panel regression to show that there is a link between stock market liquidity and investor protection. ${ }^{1}$ Finally, the paper estimates the market liquidity premium using Fama and French's (1993) approach and taking into account different hypotheses of international financial market segmentation.

\section{The main result is that strengthening corporate governance in Chile may} enhance stock market liquidity. Overall, global factors (such as changes in global risk appetite) seem to matter more than domestic macroeconomic factors (such as inflation or economic activity) in explaining the variation of stock market liquidity in Chile. By contrast, the findings suggest a more relevant role is played by a few institutional characteristics of Chile's corporate governance framework, such as the relatively poor protection of minority shareholders. ${ }^{2}$ Finally, the empirical results in part IV of this study suggest low stock market liquidity increases the cost of equity in Chile by as much as $3 \frac{1}{2}$ percent per year.

\section{Greater corporate transparency and stronger protection of shareholders' rights} could increase liquidity, potentially reducing the cost of equity or corporate leverage. International experience in the United Kingdom and Japan shows that the introduction of a voluntary (but incentivized) corporate stewardship code for corporate can enhance transparency and firm accountability to shareholders. The adoption of a similar scheme could be considered in Chile with the goal of improving transparency and liquidity in the stock market. However, a full quantification of the effects of better market liquidity on the cost of capital and firms' capital structure requires a full-blown dynamic-stochastic general equilibrium (DSGE) model, which is beyond the scope of this analysis.

\footnotetext{
${ }^{1}$ Although a structural general equilibrium model of market liquidity would be needed to fully answer some of these questions, to the best of our knowledge, there is no ready-to-use model that relates liquidity and the liquidity premium to firm or country-level governance. The empirical approach of Section 4 relies on the Capital Assets Pricing Model (CAPM), which is derived from a general equilibrium framework. Hence, the quantification of the liquidity equity premium is not entirely without a general equilibrium perspective.

2 There is no well-established model that relates market liquidity and investor protection. In fact, the theoritcal literature suggests often contradictory ways in which liquidity and governance may be related (see Edmans, 2014). Hence, the findings of Section 3 are suggestive and cannot provide a definitive answer to this question.
} 


\section{Stock Market LiQuidity in Chile}

6. Market liquidity is defined as the ease with which one can trade a significant quantity of an asset at a low cost and in a short time. Hence, liquidity includes three dimensions: quantity, time, and cost (Holden, Jacobsen, and Subrahmanyam, 2014). Although the quoted bid-ask spread is the most direct measure of the cost of trading, there are several reasons why it may not be considered an appropriate measure of liquidity, especially at a daily frequency. On the other hand, there is considerable evidence that turnover and trade volumes are not consistently related to bid-ask spreads and other liquidity measures. Therefore, most empirical measures of liquidity combine price and quantity data at various frequencies.

\section{Box 1. Why Does Liquidity in the Stock Market Matter?}

Stock market liquidity has important consequences for real economic activity and financial stability. Some of the reasons why it matters are as follows (Holden, Jacobsen, and Subrahmanyam, 2014).

- Low stock market liquidity may increase the cost of equity. With a greater liquidity risk priced in, market participants will request higher returns, and the higher cost of equity for firms could negatively affect investment. This is not the only possible outcome though: in general equilibrium, firms may respond to the higher required returns on equity by using more debt as a source of funding, leaving the weighted cost of capital unchanged.

- Low stock market liquidity might induce high leverage, by making equity more expensive. Second, less liquid stock markets may reflect information asymmetries and agency problems between firm insiders and outside investors, discouraging equity issuance.

- Low stock market liquidity may discourage private equity activity, by making initial public offerings more difficult and expensive. This has a disproportionate effect on younger firms - the most common users of these types of finance - and could reduce innovation and firm creation. High market liquidity may improve management of all firms (not just young ones) by enhancing corporate governance and increasing the effectiveness of equity-based managerial compensation.

- Low stock market liquidity impedes price discovery, reducing stock market efficiency, and increases the risk that equity valuations may become less aligned with fundamentals and thus exposed to large corrections.

7. This paper uses the price impact measure proposed by Amihud (2002), which measures by how much prices have to change to accommodate a given volume of trading. The Amihud measure is constructed as follows. 


$$
\text { Amihud }_{i t}=\frac{1}{D_{t}} \sum_{d_{t}=1}^{D_{t}} \frac{\mid \text { return }_{i d_{t}} \mid}{\text { volume }_{i d_{t}}}
$$

where $D$ is the number of days in the month (or year) $t$ when stock $i$ was traded, return is the stock $i$ daily total return, and volume is the value of transaction. When market liquidity is low, trades have a large price impact, which translates into a high Amihud value.

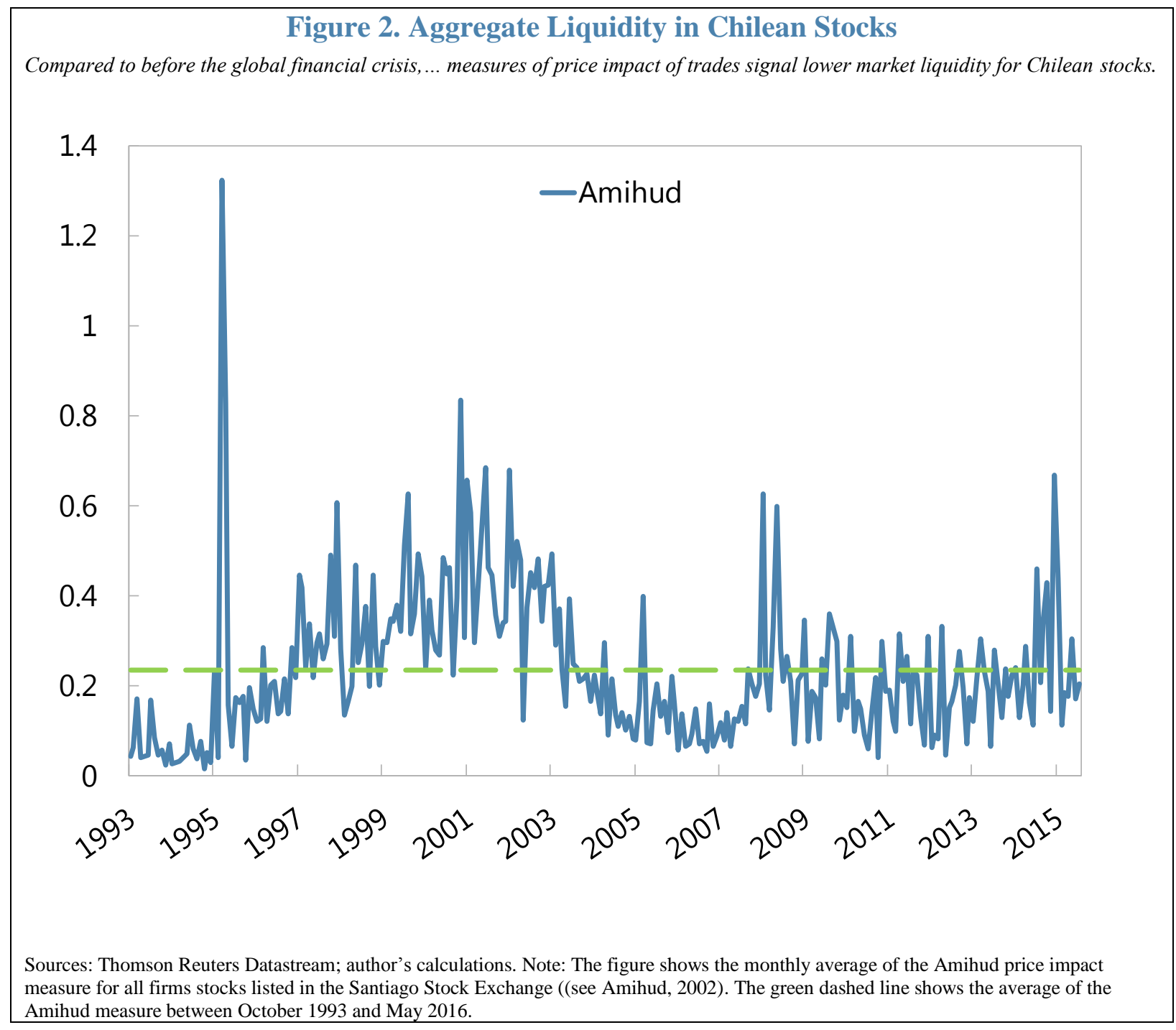

8. The Amihud measure in Chile has not returned to levels seen in 2002-06 and the gap between Chile's stock market liquidity relative to advanced economies has not narrowed (Error! Reference source not found.). According to this measure, the Chilean stock market witnessed three periods of illiquidity: in 1997-2003, 2008, and 2015. With the exception of the last period, illiquidity in Chile has been triggered by crisis events: The Asian crisis (1997) and the global financial crisis (2008). Furthermore, compared to the pre-crisis years (2004-2007), stock market liquidity has been relatively low for the last seven years. In fact, in 2015, the price impact of trades for Chilean stocks increased (meaning stock market 
liquidity deteriorated) to levels comparable to those observed during the global financial crisis.

\section{Survey based measures of liquidity also show that market liquidity in Chile} deteriorated significantly between 2010 and 2013. These measures, based on questions posed to institutional investors on how costly they find their trades, show a similar trend for both for equities and fixed income. Although many countries experienced significant changes in market liquidity during the period under study, Chile showed some of the largest moves. In fact, compared to other emerging market economies, Chile's stock market went from being one of the most liquid to being one of the least liquid (Figure 3). A similar trend is observed for fixed income, suggesting that at least some of the driving factors of market liquidity may be common to fixed income assets.

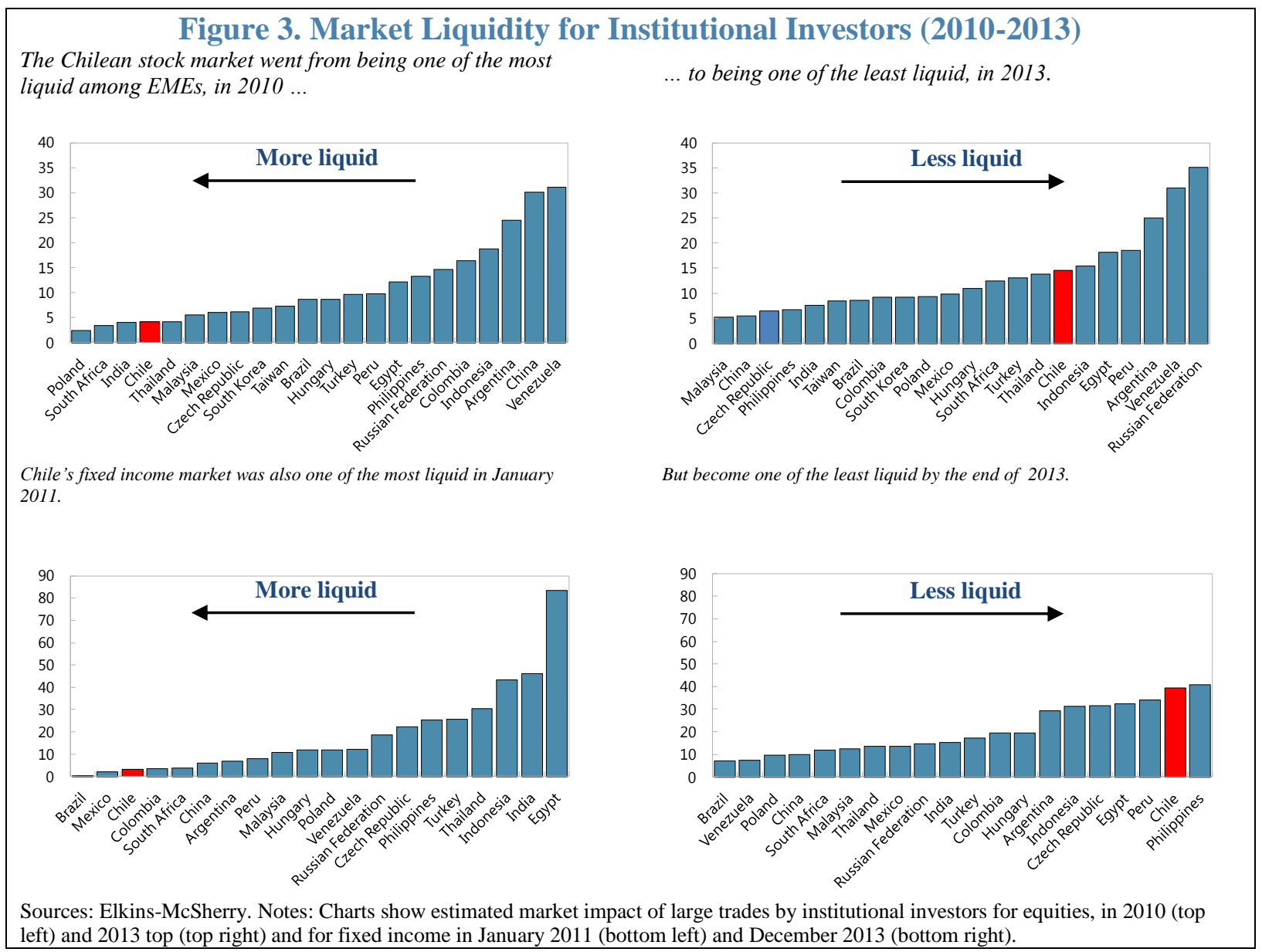

\section{Determinants of MARKet LiQuidity For ChILEAN Stocks}

10. In this section, we analyze the cyclical behavior stock market liquidity in Chile, as well of its resilience, using time series and panel regressions. First, using an aggregate stock market liquidity measure derived from the high-low spread metric described above, we 
employ a regime switching approach to estimate and explain the likelihood of the Chilean stock market being at any given point in time a high or low liquidity regime. Second, to identify the effect on liquidity of institutional characteristics, such as corporate governance and ownership structure of local stock markets, we use a panel data regression of market liquidity for a sample of 23 emerging market economies.

\section{A. Moving from high to low liquidity: The role of cyclical factors}

11. Liquidity is prone to sudden jumps and bouts of volatility and is best captured by empirical specifications which include the possibility of regime changes. We follow a time-series oriented approach by implementing Hamilton's (1989) switching regression approach, where liquidity can be in one of two possible regimes: low and high. The estimated probability of liquidity being in the low regime one month ahead provides an indication of the resiliency of liquidity (its ability to withstand shocks).

\section{Figure 4. Stock Market Liquidity Regimes in Chile}

Probability of being in a low liquidity regime peaked three times: in the Asian crisis and early 2000's, during the global financial crisis, and in 2015.

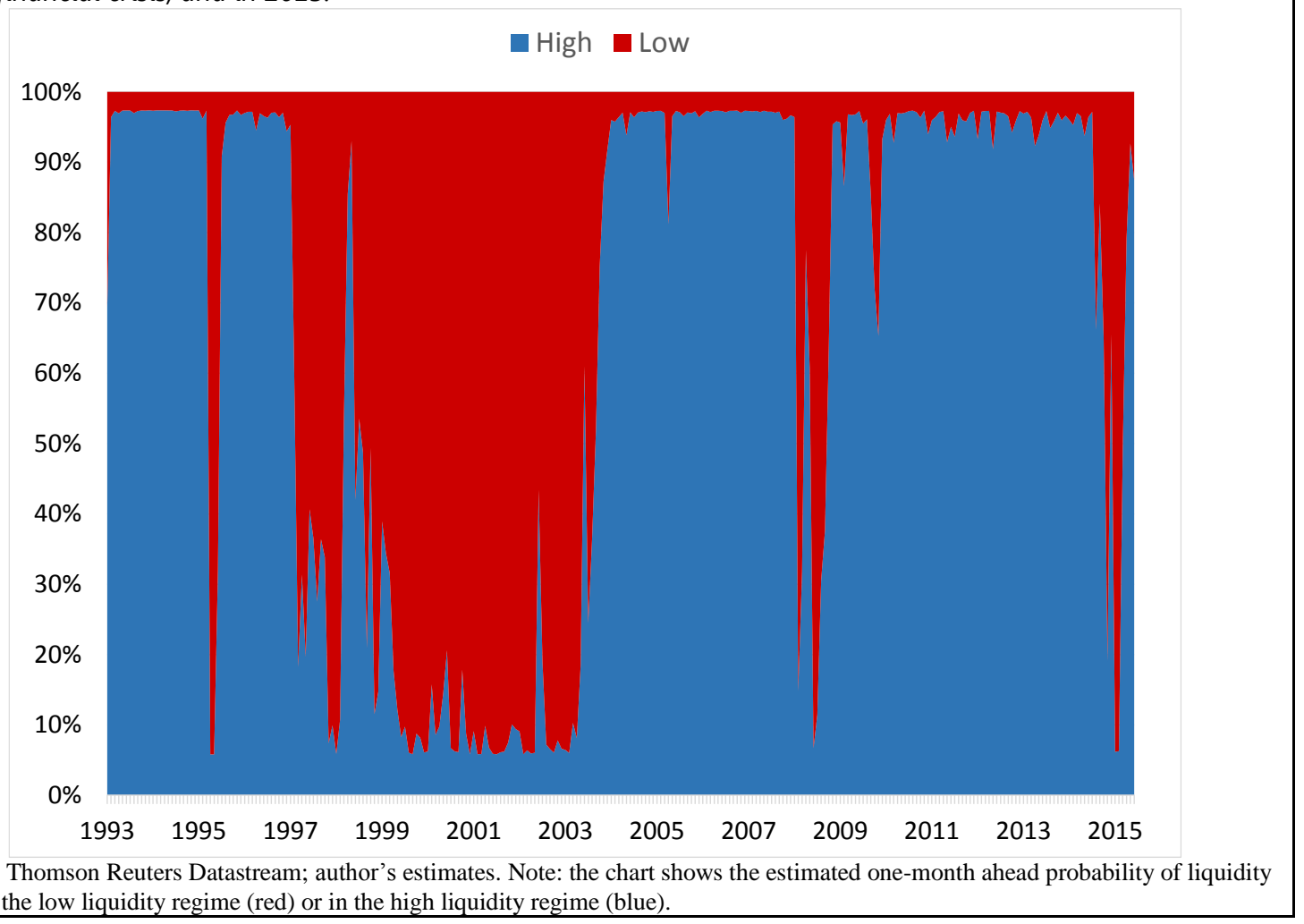

12. Since 1990, Chile's stock market experienced three periods when liquidity has not been resilient: the period starting in the Asian crisis (1997-1999) and ending with 
the dot-com bubble and 2002 recession, and the global financial crisis, and most of 2015 (Figure 4). In the first two episodes, global financial volatility was an important trigger. However, domestic factors probably contributed as well to the low resilience of liquidity in 2015.

13. Market liquidity seems to be best explained by global financial factors such as global risk aversion and the U.S. monetary policy stance (Table 1). After estimating the probability of being in one of these regimes, we relate it to observable financial and macroeconomic variables, such as global risk appetite (VIX), the U.S. monetary policy stance (federal funds target rate), an index of economic activity in the United States (the Aruoba-Diebold-Scotti-ADS — index of business conditions), and domestic macroeconomic conditions (monetary policy rate, inflation, and economic activity). The following benchmark specification suggests a significant role for global factors (Table 1).

$$
P L I Q_{t}=\beta_{0}+\beta_{1} V I X_{t}+\beta_{2} F F_{t}+\beta_{3} A D S_{t}+\beta_{4} \Delta Y_{t}+\beta_{5} \text { Infl }_{t}+\beta_{6} i_{t}+u_{t} .
$$

Table 1. Liquidity Regimes in the Chilean Stock Market

Being in a low liquidity depends mostly on global factors while domestic cyclical factors have no explanatory power.

(1)

\begin{tabular}{lc|lc}
\hline \multicolumn{1}{c|}{ Variables } & $\begin{array}{c}\text { Low Liquidity } \\
\text { Regime }\end{array}$ & \multicolumn{1}{c}{ Variables } & $\begin{array}{c}\text { Low Liquidity } \\
\text { Regime }\end{array}$ \\
\hline VIX & $0.0303^{* * *}$ & Global Factors & $0.058773^{*}$ \\
U.S. Monetary Policy & $0.0600^{*}$ & Domestic Factors & 0.035608 \\
U.S. Business Conditions & -0.0612 & Lagged Dependent Variable & $0.916097^{* * *}$ \\
Chile Economic Activity & 2.1094 & & \\
Chile Inflation & -0.0202 & & \\
Chile Monetary Policy & -0.0051 & & \\
Lagged Dependent Variable & $0.8694^{* * *}$ & & \\
& & & \\
Adjusted R-squared & 0.8549 & Adjusted R-squared & \\
\end{tabular}

Sources: Central Bank of Chile; Haver Analytics; Krippner (2016); Thomson Reuters Datastream; and author's estimates. Note: The table shows, in panel (1), the effect on the probability of the Chilean stock market being in a low liquidity regime of U.S. business conditions (measured by the Aruoba-Diebold-Scotti index of business conditions), U.S. equity market implied volatility (VIX), U.S. monetary policy (Federal Funds target rate), domestic consumer price inflation, domestic economic activity (measured by the IMACEC index), and the Chilean monetary policy rate. In panel (2), the same dependent variables is explained by the first principal component of a set of global factors (VIX, Federal Funds target rate, Aruoba-Diebold-Scotti index, Ted spread, U.S. credit spread, the U.S. term spread, and the monthly total return of the S\&P 500 composite index) and a set of domestic factors (the first principal component of the monthly growth in the IMACEC index, domestic consumer price inflation, Chilean monetary policy rate, monthly growth in bank lending to corporates, and the monthly total return of the IPSA stock index). Market liquidity is measured using Amihud's (2002) price-impact metric. The probability of being in a low-liquidity regime is estimated using a Markov-switching regression model (see appendix) and scaled using a logit transformation. The sample is at the monthly frequency, starts in November 1993, and ends in March 2016. *,**, and *** signify statistical significance at the 10,5, and 1 percent levels. See the Appendix for details on data and definitions.

14. In contrast, Chilean domestic macroeconomic conditions do not seem to explain the behavior of stock market conditions over the cycle. Domestic macroeconomic factors, 
such as monthly inflation, the monthly average of the Central Bank of Chile's monetary policy rate, and the monthly growth rate of the IMACEC economic activity index never play a significant role. However, structural factors omitted from this analysis - such as the quality of minority shareholders protection - may have contributed to the recent illiquidity of the Chilean stock market. ${ }^{3}$ The following section discusses the role of these factors.

\section{B. What explains liquidity? A cross-country regression}

\section{Market liquidity depends chiefly on the willingness and ability of financial intermediaries to act as "market makers" and on the costs of searching for counterparties for trades. When market makers are less constrained, face lower costs, or} are not concerned with asymmetric information, liquidity costs will be lower. In addition, in markets where search costs are low, such as those with many participants and good information, liquidity costs should also be low. ${ }^{4}$ Hence, we assume a country's stock market liquidity depends on: ${ }^{5}$

- Market size and depth. A stock market with a larger market capitalization should have more active traders and, in general, be more developed. A higher number of traders (or investors) mean that it will be easier to find counterparties for transactions and, hence, search costs will be lower.

- Asset volatility. When stock prices are more volatile, market making is more onerous as a higher level of risk means dealers have higher inventory costs. ${ }^{6}$ Hence, higher stock price volatility should be related to lower liquidity (higher bid-ask spreads and price impact).

- Economic and political environment. A country with high political stability and a good economic environment should, in principle, attract more investors (foreign and domestic) to its capital markets and, hence, have better liquidity.

\footnotetext{
${ }^{3}$ It is unlikely that the results could be explained by other omitted cyclical factors. In an alternative specification, other factors such as the domestic monetary policy rate, the depreciation of the Chilean peso against the U.S. dollar, and the Aruoba-Diebold-Scotti index of economic activity for the United States do not change results significantly.

${ }^{4}$ Fast and efficient dissemination of information reduces informational asymmetries and improves market liquidity because it encourages market-making activities (see Vayanos and Wang, forthcoming).

${ }^{5}$ The baseline econometric specification is similar to Lesmond (2005) and is described in more detail in the appendix.

${ }^{6}$ Financial intermediaries (dealers) make markets by posting bid and ask price quotes at which they are willing to buy or sell stocks (immediacy service). In order to do this, dealers must have a sufficient amount of stocks on their balance sheets which are available for sale, that is, they must carry inventories. The difference between the ask and the bid price (the bidask spread) is the compensation the market maker requires for carrying these inventories and providing immediacy services. Among other things, this spread must cover the opportunity cost and the risk implicit in carrying such inventories. Riskier assets, obviously, are more expensive to be held in inventory.
} 
- Global investor risk appetite and financial volatility. In periods of high global risk appetite and low volatility liquidity should be higher (thanks to greater global investor interest in participating in local markets). Conversely, in periods of high financial volatility, market makers will more likely face financial constraints and will be less able to provide liquidity services.

- Institutional quality related to corporate governance. Better corporate governance and investor protection, by reducing the potential for information asymmetries, should encourage trading activity and improve market liquidity. When the protection of minority shareholders is effectively low, there will be fewer traders available (hence, higher search costs) and market makers will require higher compensation because of corporate insiders exploiting asymmetric information and extracting rents from other market participants. Both factors lead to lower liquidity (see Box 2).

16. To assess the importance of these factors we run a panel regression. Since many of these factors are slow moving, they can only be addressed empirically if there is enough cross-country variation. Therefore, we study market liquidity at the country level (using the Amihud measure of liquidity) through a panel of 23 emerging market economies (based on the list of countries in the MSCI Emerging Market Index) covering the 2003-2014 period. ${ }^{7}$ The sample is summarized in Appendix Table 1 and estimation results are shown in Error! Reference source not found.. Initially, we consider the following econometric specification.

$$
\begin{aligned}
\text { Amihud }_{i t}= & \alpha_{i}+\gamma_{i} t+\beta_{1} \text { VIX }_{t}+\beta_{2} \text { MarketDepth }_{i t-1}+\beta_{3} \text { Volatility }_{i t-1}+\beta_{4} \Delta G D P_{i t}+ \\
& \beta_{5} \text { Inflation }_{i t}+\beta_{6} \text { PoliticalRisk }_{i t}+\beta_{7} \text { Shareholders }_{i t}+\varepsilon_{i t},
\end{aligned}
$$

where MarketDepth is the ratio of stock market capitalization to GDP, Volatility is the standard deviation of daily stock returns for each year and country, ${ }^{8} \Delta G D P$ is the growth rate of real GDP, Inflation is the annual rate of inflation implicit in the GDP deflator, PoliticalRisk is the ICRG's political risk rating, and Shareholders is the perception of minority shareholder protection from the World Economic Forum (see the Appendix for details on data sources and variable definitions). ${ }^{9}$ The specification includes country fixed effects to control for unobserved time-invariant country characteristics that can be correlated

\footnotetext{
${ }^{7}$ The length of the sample is restricted by data availability. The study uses the Amihud measure to proxy market illiquidity.

${ }^{8}$ Market capitalization (market depth) and stock market volatility are lagged one period because they may be jointly determined with stock market liquidity (price impact).

${ }^{9}$ The index calculated by the World Economic Forum for its annual Global Competitiveness Report ranks countries is based on a survey of local investors, and analysts where they are asked about their perception of the protection of interests of minority shareholders in their countries. Conceivably, the question covers the perception of both external corporate governance (country-level laws and institutions that establish and uphold governance requirements) and internal corporate governance (the actual protection of the interests of minority shareholders by firms' bylaws and practices).
} 
with the selected covariates. In addition, the specification includes country-specific time trends to control for different market and investor protection trends across countries. ${ }^{10}$

\section{Although Chile's investor protection is still somewhat better than average, the} country has lost some ground since 2004. The perception of how protected investors are fell by 12 percent in Chile between 2004 and 2014, while it increased slightly (by less than 3 percent) on average for all EMs. In fact, Chile enjoyed the third highest level of minority shareholder protection (as perceived by the public) in 2004 but was ranked ninth (out of 23) in 2014. In terms of stock market liquidity, however, Chile always ranked among the bottom third of the sample, with the $17^{\text {th }}$ lowest level of liquidity among 23 countries, in 2014.

\section{The results suggest that better protection of minority shareholders is associated} with improved market liquidity (Error! Reference source not found.). The study shows that improving the protection of minority shareholders is associated with better market liquidity. ${ }^{11}$ ${ }^{12}$ Based on the results, strengthening the protection of minority shareholders in Chile (to the highest level among EM economies) would increase market liquidity by about 30 percent. ${ }^{13}$

\section{Better protection of minority shareholders is still associated with better market} liquidity when alternative hypotheses are considered. The results in Error! Reference source not found. do not change in a significant way when the benchmark specification is extended in order to take into account a variety of possible misspecifications (see the Appendix for details).

a. Corporate ownership structure. In countries where corporate conglomerates are large (high cross holdings) and own a substantial portion of the country's market capitalization, liquidity could be low because of the relatively lower degree of transparency. Furthermore, higher cross holdings are usually associated with lower ownership by institutional investors, who usually

\footnotetext{
${ }^{10}$ For instance, countries market liquidity may be improving in some countries because of financial deepening. In addition, investor protection and corporate governance may be improving because of the well-documented convergence of corporate governance (Gilson, 2001).

${ }^{11}$ Although corporate governance may have an effect on liquidity, causality probably runs both ways (see Holden and others, 2014). On the one hand, better liquidity may discourage investors from pressing for better management and governance practices by reducing exit costs (Bhide, 1993). However, this would work against finding a positive association between liquidity and investor protection, as reported in Error! Reference source not found.. On the other hand, better liquidity may increase the benfits of monitoring or encourage the formation of blockholders who will monitor management (Maug, 1998 and Bharath, Jayaraman, and Nagar, 2013). Unfortunately, in this context, it is difficult to come up with valid instruments. Therefore, although it is not clear whether reverse causality will lead to an under- or overestimation of the association between stock market liquidity and investor protection, causal implications must be interpreted with care.

12 This novel result is different from what has been previously found in the empirical literature. For instance, Lesmond (2005) finds that the quality of legal and political institutions improves market liquidity, but finds no evidence that better corporate governance and investor protection has the same effect.

${ }^{13}$ This would entail Chile leaping from the $42^{\text {nd }}$ place to the $2^{\text {nd }}$ place in the World Economic Forum's worldwide ranking in this category, catching up with South Africa. See Appendix Table 1 for sample summary statistics.
} 
require greater transparency. When transparency is low, there is a greater scope for asymmetric information to be used to the disadvantage of market makers who, in turn, will require higher bid-ask spreads. Although cross ownership seems to be associated with lower liquidity, the significance of shareholder protection is not diminished (column (2) of Error! Reference source not found.). In addition, shareholder protection seems to have a stronger economic significance: reducing cross-ownership by other companies in Chile (currently, about 40 percent of market capitalization on average) to the lowest value observed in the sample (Qatar, at 8 percent) would be associated with an increase in market liquidity of less than 15 percent.

Table 2. Market Liquidity, Ownership Concentration, and Shareholder Protection

Concentration of ownership contributes to reduced liquidity, but a strong protection of minority shareholders improves liquidity in countries with strong legal systems.

Variables

(1)

Volatility

Market Capitalization

Volatility

GDP Growth

Inflation

Political Risk

Protection of Minority Shareholders

Cross Holdings

Institutional Ownership

Rule of Law

Quality of Regulation

\section{Observations}

$R$-squared

Number of Countries
(2)

(3)

(4)

(5)

(6)

Sources: Thomson Reuters Datastream; FactSet; IFS; World Economic Outlook; PRS Group - International Country Risk Guide (ICRG); World Economic Forum - Global Competitiveness Indicators; World Bank - Worldwide Governance Indicators; author's calculations. Note: The table shows slope coefficient estimates of a fixed effects regression of the Amihud measure of illiquidity on the variables listed in the first column to the left. The data frequency is annual and estimation period is $2002-2014$. Robust standard errors (clustered at the country level) in parentheses: $* * * \mathrm{p}<0.01, * * \mathrm{p}<0.05, * \mathrm{p}<0.1$.

b. Institutional investors. The importance of institutional investors such as insurance companies, mutual funds, and pension funds varies greatly from 
country to country. In addition, pension funds and long-term investors also seem to demand stocks of firms with better corporate governance and push for improvements in governance (Aggarwal and others 2011 and McCahery, Sautner, and Starks, forthcoming). Hence, it is possible that the positive association between investor protection and liquidity merely reflects the crosscountry variation of the importance of institutional investors. To control for the importance of institutional investors we add as an additional control the average share of ownership by institutional investors of the stocks in each country index. The results, in column (3) of Error! Reference source not found., are very similar to those of the benchmark regression. ${ }^{15}$

c. Rule of Law. It is possible that market liquidity depends more generally on the quality of the legal system. In particular, it could be that the positive association between market liquidity and better investor protection is in effect masking an association between the former and the quality of the legal institutions in general. However, the results in column (4) of Error! Reference source not found. suggest that the protection of minority shareholders is still significantly associated with better stock market liquidity even after controlling for the quality of the rule of law (measured by the Rule of Law index by the World Bank).

d. Regulatory quality. Finally, we check whether the results remain when we use a different variable of institutional quality - the World Bank's index of the quality of regulation in the country. The results (column (5) of Table 2) show that although the quality of regulation matters for liquidity, so does the protection of minority shareholders. Finally, when alternative explanations are included in one regression, among the institutional quality variables, only the protection of minority shareholders retains explanatory power.

Box 2. Shareholder Protection, Corporate Governance, and Market Liquidity

Economic theory suggests a positive link between corporate transparency and stock market liquidity. When different investors have different information about stocks, liquidity suffers. In theory, investors with better information are likely to make money at the expense of less informed investors. Therefore, market makers are less willing to provide liquidity services (lower market depth) or will charge higher bid-ask spreads if they think they are likely to encounter an investor with superior information on the other end of a trade. Better corporate

\footnotetext{
${ }^{15}$ In principle, some institutional investors such as insurance companies and pension funds favor buy-and-hold investment strategies and are typically considered to have a low demand for liquidity and do not trade often. On the other hand, foreign institutional investors have a preference for highly liquid assets (Dahlquist and Robertsson 2001). This suggests possible reverse causality between institutional ownership and liquidity. Unfortunately, instrumental variables for ownership are not readily available. See Edmans (2014) for a review of the literature on institutional investors, liquidity, and corporate governance.
} 
governance and shareholder protection may improve stock market liquidity by reducing the scope for differences in information (or information asymmetries) between insiders (managers and large shareholders) and outsiders (the providers of external finance). In turn, a reduction in information asymmetries should improve liquidity (see Fernandes, Igan, and Pinheiro, 2015 for empirical evidence, for instance).

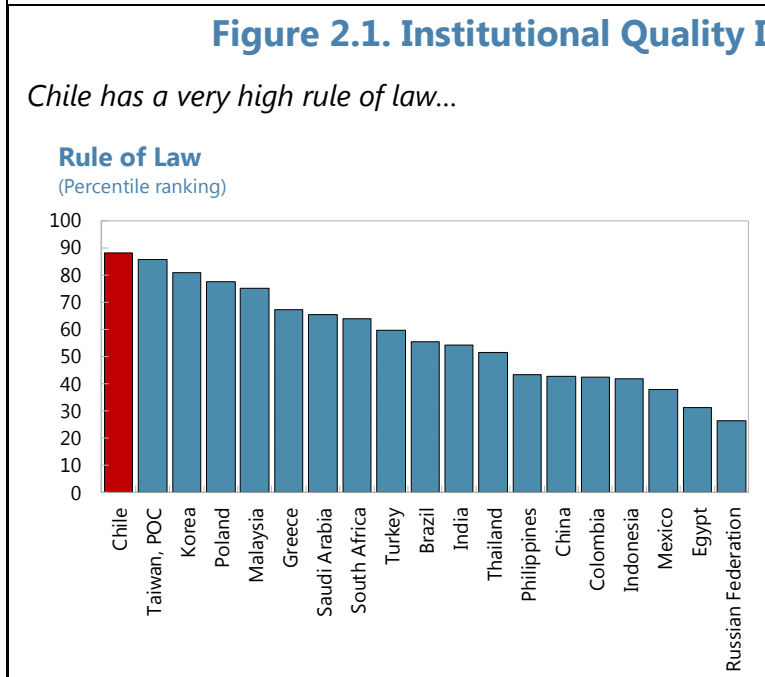

The measured quality of corporate governance is low...

Quality of Corporate Governance in Emerging Markets (Index; 0-100)

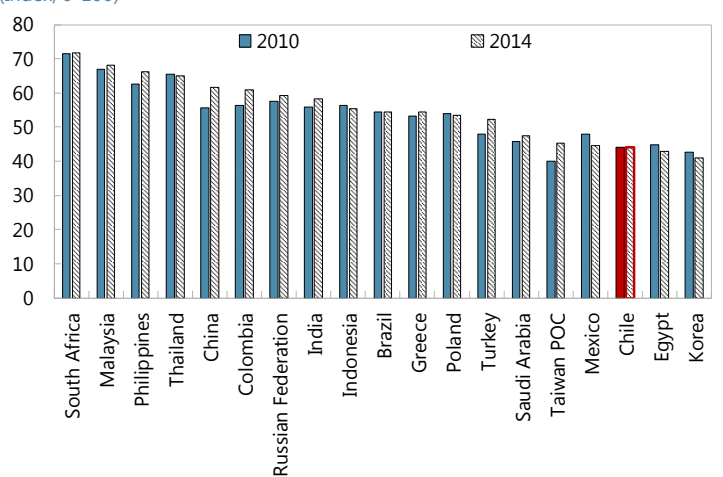

ators for Select Emerging Markets

... but the public perception of the protection of minority shareholders has weakened.

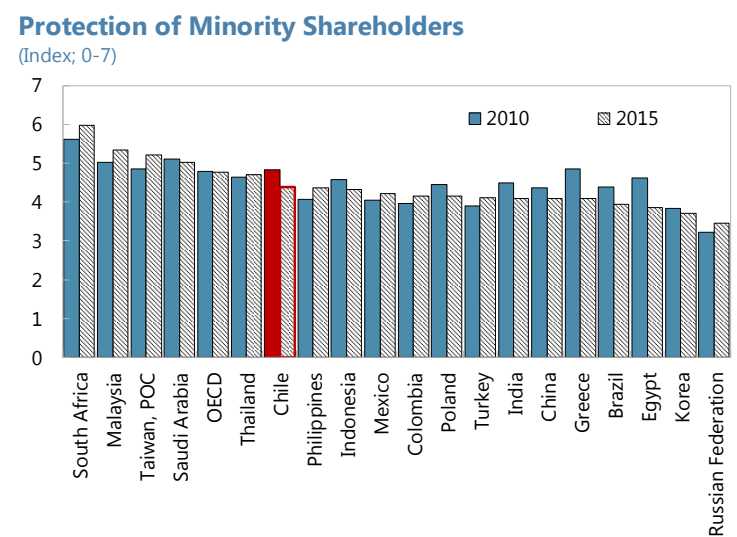

... and Chilean firms are very opaque.

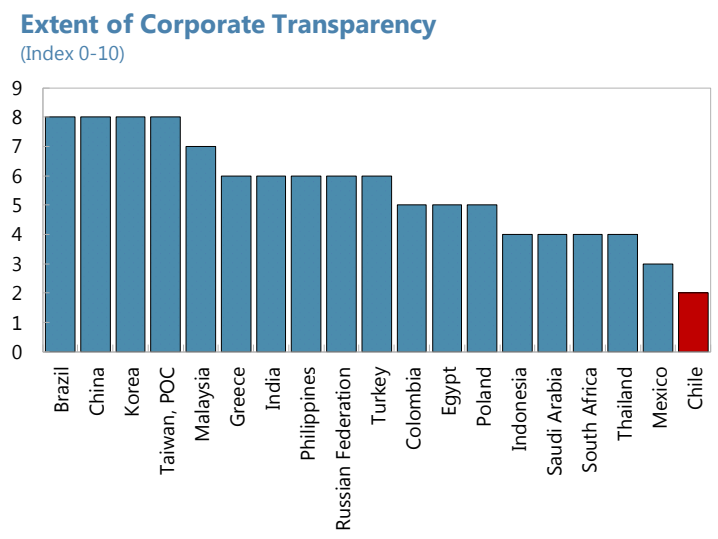

Sources: Albuquerque and others (2016); Thomson Reuters Datastream; World Bank; World Economic Forum; author's calculations.

Regulatory environments and corporate governance practices that protect the interests of minority shareholders are more conducive to higher corporate transparency. For instance, independent audit committees tend to curb managerial discretion in terms of financial disclosure. In addition, when governance practices make management teams more accountable - either by facilitating the removal of nonperforming executives or by increasing monitoring by independent boards - it becomes easier for investors to discern the quality of management and firm value.

Previous empirical studies have found some support for the hypothesis that better corporate governance and investor protection improve market liquidity. The quality of the judicial system and political risk have been shown to be associated with better liquidity in emerging markets (Lesmond, 2005). In countries with high investor protection, firms from 
countries with poor investor protection that trade in exchanges of those countries have worse liquidity than domestic firms (Brockman and Chung, 2003). In addition, firms that adopt corporate governance provisions that enhance firm financial and operational transparency have significantly better market liquidity (Chung, Elder, and Kim, 2010).

Although Chile, in general, has high-quality institutions, it ranks less favorably in terms of shareholder protection, corporate governance, and corporate transparency. In a sample of 20 emerging markets, Chile has the highest quality of the rule of law and displays very low corruption and a superior quality of regulation (Figure 2.1). However, the public's perception of the strength of shareholder protection is below the OECD average and the country has the opaquest corporate sector among all emerging markets. In addition, its largest corporations, on average, display low corporate governance scores (see Albuquerque and others, 2016, for details). Although the discrepancy between the general quality of institutions and the level of corporate governance and transparency in Chile is certainly due to more than one factor, the highly concentrated ownership and the prevalence of conglomerates is a possible contributing factor (OECD, 2015a and 2015b).

\section{STOCK LIQUIDITY AND ASSET PRICING IN CHILE}

\section{This study analyzes the cost of low stock market liquidity by estimating the} liquidity premium of Chilean stocks. We estimate the additional return required by investors to hold the illiquid stocks relative to liquid ones using a standard Fama-French empirical asset-pricing model and data from 220 ordinary stocks listed in Chilean exchanges from January 1993 to March 2015. The exercise consists in ranking all traded Chilean stocks (primary securities traded in Chile, only) in each month and then forming four (equal-sized) portfolios with increasing levels of market liquidity. Then, it estimates the abnormal return of each portfolio, that is, the part of returns that cannot be explained by their comovement with the market portfolio or by any other know factor (size and growth). ${ }^{16}$ the $\alpha$ 's in the following regressions of the portfolios' excess return (in U.S. dollars and relative to the 3-month U.S. Treasury bill rate).

$$
\begin{aligned}
& r_{i t}=\alpha_{i}+\beta_{i}^{w} r_{t}^{w}+\beta_{i}^{H} H M L_{t}^{w}+\beta_{i}^{S} S M B_{t}^{w}+\varepsilon_{i t}, \text { and } \\
& r_{i t}=\alpha_{i}+\beta_{i}^{d} r_{t}^{d}+\beta_{i}^{w} r_{t}^{w}+\beta_{i}^{H} H M L_{t}^{w}+\beta_{i}^{S} S M B_{t}^{w}+\varepsilon_{i t},
\end{aligned}
$$

\footnotetext{
${ }^{16}$ In the asset pricing literature, in addition to the returns of market portfolio, several other factors have been identified as potentially explain stock returns. The current section uses two of such factors. First, it uses the difference in returns between small and large firms. Second, it uses the difference in returns between firms with high price-to-book value (growth firms) and those that have a low price-to-book value (value firms). See Fama and French (1993).
} 
where $r_{i}$ is the excess return of portfolio $i, r^{w}$ is the excess return of the world market portfolio, $H M L^{w}$ is the return on the value versus growth world portfolio, and $S M B^{w}$ is the return in the small firm versus large firm world portfolio. Finally, $r^{d}$ is the aggregate excess return of the Chilean stock market.

21. The study finds that less liquid stocks earn higher abnormal returns. ${ }^{17}$ The analysis uses different assumptions about how integrated the Chilean equity market is with global financial markets. In the first specification, it assumes that the Chilean market is fully integrated with global financial markets and, for that reason, only the global factors $\left(r^{w}\right.$, $H M L^{w}$, and $\underline{S M B^{w}}$ ) matter for equity prices in Chile. In the second specification, it assumes that either Chilean investors cannot freely invest foreign assets. In this case, the domestic market returns should also matter because there are limits to the diversification of risk using foreign assets. In both cases - partial segmentation and complete financial integration - but the estimates are similar.

\section{The results are robust when the analysis takes into account the changes that} Chilean financial markets went through in the 1990s. Because Chile's economy and financial markets underwent significant structural changes in the 1990s, as well as capital controls which restrict capital inflows, the analysis is also performed for the 2002-2015 period only and yields similar results. ${ }^{18}$ The choice of the smaller sample period is warranted by the existence of capital controls until 1998 (although probably ineffective since 1997), which may have affected firms differently depending on their size (see Forbes 2007). In both cases, investors seemed to have required higher returns to hold the least liquid stocks.

\section{This simple asset pricing exercise suggests that lower stock market liquidity may} result in a significantly higher cost of equity (Table 3). The monthly excess required return associated with the least liquid stocks is about 0.3 percent, which translates into roughly $31 / 2$ percent per annum, if one only uses data for 2002-2015. The estimate means that improving liquidity of the least liquid Chilean shares would reduce their cost of equity by $31 / 2$ percentage points. The full sample (1993-2015) suggests higher estimates at around 41/2 percent per annum. Other studies using data from the United States (Pastor and Stambaugh, 2003) or from cross-country studies (Amihud, Hameed, Kang, and Zhang, 2015) suggest annualized gains can be even more substantial. In fact, Amihud and others estimate the liquidity premium for Chilean stocks to be between 0.4 and 1 percent.

\footnotetext{
${ }^{17}$ See the Appendix for details and some important caveats.

18 The empirical literature on liquidity and expected returns suggests taking into account different hypothesis in terms of market integration and time-varying market development (Bekaert, Harvey, and Lundblad, 2007).
} 
Table 3. Abnormal Returns and Liquidity

The most illiquid stocks require a sizeable return above what is granted by the market model.

\begin{tabular}{rccrc}
$2002-2015$ & & & \\
Portfolio & $\alpha_{\mathrm{L}}$ & $\alpha_{\mathrm{W}}$ & Amihud & $\begin{array}{c}\text { Number of } \\
\text { Shares }\end{array}$ \\
\hline 1 & 0.1086 & 0.3312 & 1.0370 & 41.3396 \\
2 & 0.0693 & 0.3302 & 0.0984 & 42.3774 \\
3 & 0.0191 & 0.2660 & 0.0236 & 42.3774 \\
4 & -0.1893 & 0.0865 & 0.0026 & 42.0943 \\
\hline & 0.2978 & 0.2447 & & \\
\hline & $(0.000)$ & $(0.000)$ & & \\
\hline
\end{tabular}

Full sample (1993-2015)

\begin{tabular}{ccccc}
\hline Portfolio & $\alpha_{\mathrm{L}}$ & $\alpha_{\mathrm{w}}$ & Amihud & $\begin{array}{c}\text { Number of } \\
\text { Shares }\end{array}$ \\
\hline 1 & 0.1422 & 0.2378 & 1.0700 & 36.8171 \\
& & & & \\
2 & -0.0313 & 0.1291 & 0.1068 & 37.8405 \\
3 & -0.0469 & 0.0870 & 0.0270 & 37.8405 \\
4 & -0.2388 & -0.0814 & 0.0041 & 37.5837 \\
\hline $1-4$ & 0.3810 & 0.3191 & & \\
& $(0.000)$ & $(0.000)$ & & \\
\hline
\end{tabular}

Sources: Kenneth French and Thomson Reuters Datastream; author's estimates. Note: The table shows estimates of the intercept coefficients in two regressions of excess returns on pricing factors. $\alpha_{L}$ is the intercept of a regression of excess returns on the local market excess returns, global market excess returns, and global SMB and HML factors, and $\alpha_{W}$ is the analogue from a regression without the local market factor. Portfolio 1 is the least liquid and portfolio 4 the most liquid. 1-4 is the abnormal return of going long on the least liquid portfolio and short on the most liquid. P-values are reported in parenthesis. The last column reports the average number of stocks in each portfolio.

\section{Policy Discussion AND CONCLUSIONS}

\section{Chile's stock market is large even when compared to developed economies but}

its market liquidity is relatively lower. Although not the only cause of low market liquidity, poor investor protection appears to be a potentially important determinant of liquidity in a country with otherwise strong institutions such as Chile. The ownership structure of most listed Chilean companies - with significant cross holdings by other corporations - also seems to play a direct role, but is probably a less important determinant.

\section{International experience offers avenues for Chile to enhance corporate} governance and liquidity. Policies that could ameliorate stock market liquidity include enhancing the protection of minority shareholders and strengthening conglomerate supervision. ${ }^{19}$ Given that ownership among Chile's corporate sector is highly concentrated

\footnotetext{
${ }^{19}$ Improving the governance of local stock exchanges, namely through their demutualization, may also enhance the efficiency of local stock markets and improve their liquidity. On the importance of the demutualization for the efficiency of
} 
and dominated by pyramid structures, targeted measures to improve corporate transparency are likely to be crucial. In particular, Chilean authorities could weigh the benefits of implementing a more binding implementation of corporate governance rules instead of current "comply-or-explain" approach. ${ }^{20}$ In addition, institutional investors such as pension funds could play a more forceful role, namely through the adoption of a stewardship code. Adoption of such a voluntary corporate responsibility and transparency code could be incentivized by linking it to the introduction of a "high-corporate quality" index on the stock market that would allow investors to identify and track listed companies with a superior standard in corporate governance (Box 3).

26. Structurally improving market liquidity may be a good antidote against shorter term fluctuations induced by global cyclical factors. This study finds that the cyclical behavior of stock market liquidity in Chile is strongly influenced by global cyclical conditions, including global risk appetite and monetary policy conditions in advanced economies (Table 1). However, more liquid markets are more resilient to changes in global financial conditions (IMF, 2014). In addition, because there are important market liquidity spillovers across asset classes (IMF, 2015), better liquidity the Chilean stock market may improve liquidity conditions in other domestic financial markets, namely in the corporate bond market. ${ }^{21}$ Hence, improving structural stock market liquidity by strengthening investor protection in Chile may mitigate the adverse effects of less benign global cyclical conditions. ${ }^{22}$

\section{Box 3. International Policies to Enhance Corporate Governance}

Ownership by institutional investors such as mutual funds, insurance companies, and pension funds is typically associated with better firm governance. Studies using data from U.S. companies have found some evidence supporting the notion that higher institutional ownership causes improvements in firm governance (Crane, Michenaud, and Weston, 2016). In addition, the engagement of institutional investors with firm governance seems stronger when they are large blockholders with a long investment horizon (MCahery, Sautner, and Starks, forthcoming).

exchanges see Elliot (2002) and Krishnamurthy, Sequeira, and Fagjian (2003). Chile's largest stock exchange, the Bolsa de Comercio de Santiago, has recently started its demutualization (March 2016).

${ }^{20}$ Currently, Chile's securities and insurance supervisor (SVS) requires listed firms to disclose information on their corporate governance practices (SVS Rule No. 385). However, the rules are not binding and a survey by the SVS reported that compliance was typically low and explanations scarce (SVS, 2015).

${ }^{21}$ See also Chordia, Sarkar, and Subrahmanyam, 2005 for liquidity spillovers between equities and bonds.

${ }^{22}$ Corporate governance reforms may have the added benefit of increasing the resilience of Chile's financial markets to global shocks through various channels other than market liquidity (see Johnson and others, 2000). 
Recently, in response to cries that institutional investors were not sufficiently engaged with the companies where they invest, some countries have published stewardship codes. The goal of these codes is to ensure that institutional investors are effectively engaged in the promotion of long-term success of the companies they own. The United Kingdom, in 2010, was the first country to publish a stewardship code defining principles for institutional investors to engage with firms and foster good corporate governance, on a "comply or explain" basis. Other jurisdictions have published their own stewardship codes (The Netherlands and South Africa in 2011, Italy and Switzerland in 2013, Japan and Malaysia in 2014, and Hong Kong S.A.R. in 2016) or at various stages of discussion and preparation (Brazil, Korea, Singapore, and Taiwan, Province of China).

Stewardship codes typically use a "principle-based" approach to increase disclosure and encourage monitoring by institutional investors. For example, the UK Stewardship Code rests on seven principles (Roach, 2011): (1) disclosure of discharge of steward responsibilities; (2) disclosure of conflicts of interest; (3) obligation to monitor investee companies; (4) clear guidelines for the escalation of stewardship activities; (5) availability for collective action with other institutional investors; (6) clear policy for voting and disclosure of voting activity; and (7) obligation of period reporting.

Japan introduced a stewardship code for institutional investors prepared at the request of the Prime Minister and with ample participation by the civil society organized under a Council of Experts. Just like in the United Kingdom, the Japanese code defines principles considered to be helpful for institutional investors to fulfill their "stewardship responsibilities." These responsibilities include enhancing the medium- to long-term investment return for their clients and beneficiaries through constructive engagement and purposeful dialogue with investee companies (Aoyagi and Ganelli, 2014). The Japan Stewardship Code states that institutional investors should have in-depth knowledge of the companies they invest in, as well as of their business environment, and they should monitor those companies. In addition, it states that institutional investors should: (1) have a clear and transparent policy on how to fulfill their stewardship responsibilities; (2) a policy to manage conflicts of interest; (3) constructively engage the investee companies; (4) have a clear and transparent policy on voting activity; and (5) periodically report on the fulfillment of their stewardship responsibilities.

Both the Japan and the UK stewardship codes adopt a "principles-based approach" and the adoption of their principles is voluntary. For instance, in Japan, there is the expectation that institutional investors should fulfill their stewardship responsibilities but the Code is not binding. The Council of Experts recommended that the Code should be revised and updated every three years. In Japan, as of July 2016, 212 institutional investors have adopted the code including 150 investment managers and close to 50 pension and insurance funds. The uptake was incentivized by the introduction of a new Nikkei 400 index of the most profitable and best governed listed companies on the Tokyo stock market. 


\section{References}

Aggarwal, Reena, Isil Erel, Miguel Ferreira, and Pedro Matos, 2011. "Does governance travel around the world? Evidence from institutional investors." Journal of Financial Economics 100, no. 1: 154-181.

Albuquerque, Rui A., Luis Brandao-Marques, Miguel A. Ferreira and Pedro Matos, 2016, "International Corporate Governance Spillovers: Evidence from Cross-Border Mergers and Acquisitions,” (under revision). CEPR Discussion Paper No. DP10917.

Amihud, Yakov, 2002. "Illiquidity and Stock Returns: Cross-Section and Time-Series Effects." Journal of Financial Markets 5, no. 1: 31-56.

Amihud, Yakov, Allaudeen Hameed, Wenjin Kang, and Huiping Zhang, 2015. "The Illiquidity Premium: International Evidence." Journal of Financial Economics 117, no. 2: 350-368.

Asparouhova, Elena, Hendrik Bessembinder, and Ivalina Kalcheva, 2010. "Liquidity Biases in Asset Pricing Tests." Journal of Financial Economics 96, 215-237.

Aoyagi, Chie and Giovanni Ganelli, 2014. "Unstash the Cash! Corporate Governance Reform in Japan.” IMF Working Paper No. 14/140.

Bekaert, Geert, Campbell R. Harvey, and Christian Lundblad, 2007. "Liquidity and Expected Returns: Lessons from Emerging Markets," Review of Financial Studies 20 (6): 1783-1831.

Bharath, Sreedhar T., Sudarshan Jayaraman, and Venky Nagar, 2013. "Exit as Governance: An Empirical Analysis." The Journal of Finance 68, no. 6: 2515-2547.

Bhide, Amar, 1993. "The Hidden Costs of Stock Market Liquidity." Journal of Financial Economics 34, no. 1: 31-51.

Brockman, Paul and Dennis Y. Chung, 2003. "Investor Protection and Firm Liquidity." The Journal of Finance, 58: 921-937.

Butler, Alexander W., Gustavo Grullon, and James P. Weston, 2005. "Stock Market Liquidity And The Cost Of Issuing Equity." Journal of Financial and Quantitative Analysis 40, no. 02: 331-348.

Chordia, Tarun, Asani Sarkar, and Avanidhar Subrahmanyam, 2005. "An Empirical Analysis of Stock and Bond Market Liquidity." Review of Financial Studies 18, no. 1: 85-129. 
Chung, Kee H., John Elder, and Jang-Chul Kim, 2010. "Corporate Governance and Liquidity," Journal of Financial and Quantitative Analysis, Volume 45(2): 265-291.

Corwin, Shane A., and Paul Schultz, 2012. "A Simple Way to Estimate Bid-Ask Spreads From Daily High and Low Prices." The Journal of Finance 67, no. 2: 719-760.

Crane, Alan D., Sébastien Michenaud, and James P. Weston, 2016. "The effect of institutional ownership on payout policy: Evidence from index thresholds." Review of Financial Studies, 29(6): 1377-1408.

Dahlquist, Magnus, and Göran Robertsson, 2001. "Direct Foreign Ownership, Institutional Investors, and Firm Characteristics." Journal of Financial Economics 59, no. 3, pp. 413-440.

Driscoll, John C., and Aart C. Kraay, 1998. "Consistent covariance matrix estimation with spatially dependent panel data," Review of Economics and Statistics Volume 80(4): 549-560.

Edmans, Alex, 2014. "Blockholders and Corporate Governance." The Annual Review of Financial Economics 6: 23-50.

Elliot, Jennifer, 2002. "Demutualization of Securities Exchanges: A Regulatory Perspective," IMF Working Paper No. 02/119.

Errunza, Vihang, and Etienne Losq, 1985. "International Asset Pricing Under Mild Segmentation: Theory and Test." The Journal of Finance 40, no. 1: 105-124.

Fama, Eugene F., and Kenneth R. French, 1993. "Common risk factors in the returns on stocks and bonds." Journal of Financial Economics 33, no. 1: 3-56.

Fernandes, Marcelo, Deniz Igan, and Marcelo Pinheiro, 2015. "March Madness in Wall Street: (What) Does the Market Learn from Stress Tests?” IMF Working Paper No. 15/271.

Forbes, Kristin 2007. "One cost of the Chilean capital controls: increased financial constraints for smaller traded firms." Journal of International Economics 71, no. 2: 294-323.

Gilson, Ronald J. 2001. "Globalizing corporate governance: Convergence of form or function." The American Journal of Comparative Law 49, no. 2: 329-357.

Hamilton, James, 1989 "A new approach to the economic analysis of nonstationary time series and the business cycle." Econometrica 57, no. 2: 357-384. 
Holden, Craig W., Stacey E. Jacobsen, and Avanidhar Subrahmanyam, 2014. "The empirical analysis of liquidity." Kelley School of Business Research Paper 2014-09.

IMF, 2014. "How do Changes in the Investor Base and Financial Deepening Affect Emerging Market Economies?" in Global Financial Stability Report, April 2014, Chapter 2. , 2015. "Market Liquidity: Resilient or Fleeting?" in Global Financial Stability Report, October 2015, Chapter 2.

Johnson, Timothy C. 2008. "Volume, liquidity, and liquidity risk." Journal of Financial Economics 87, no. 2: 388-417.

Johnson, Simon, Peter Boone, Alasdair Breach, and Eric Friedman, 2010. "Corporate governance in the Asian financial crisis." Journal of Financial Economics 58, no. 1: 141-186.

Krippner, Leo. 2016. "Measures of the Stance of United States Monetary Policy." Reserve Bank of New Zealand. Accessed April 4, 2016. http://www.rbnz.govt.nz/research-andpublications/research-programme/additional-research/measures-of-the-stance-of-unitedstates-monetary-policy.

Krishnamurti, Chandrasekhar, John M. Sequeira, and Fu Fangjian, 2003. "Stock exchange governance and market quality." Journal of Banking and Finance 27, no. 9: 1859-1878.

Lesmond, David A. 2005. "Liquidity of emerging markets." Journal of Financial Economics 77, no. 2: 411-452.

McCahery, Joseph A., Zacharias Sautner, and Laura T. Starks, Forthcoming. "Behind the Scenes: The Corporate Governance Preferences of Institutional Investors," Journal of Finance.

OECD, 2015a. "International and Latin American overview", in Corporate Governance of Company Groups in Latin America, OECD Publishing, Paris.

OECD, 2015b. "Chile”, in Corporate Governance of Company Groups in Latin America, OECD Publishing, Paris.

O'Hara, Maureen, and Alfredo M. Mendiola, 2003. "Taking stock in stock markets: the changing governance of exchanges." Available at SSRN 431580.

Pástor, Lubos, and Robert F. Stambaugh, 2003. "Liquidity Risk and Expected Stock Retums." The Journal of Political Economy 111: 642-685. 
Roach, Lee, 2011. "The UK Stewardship Code.” Journal of Corporate Law Studies, Vol. II, Part 2: 463-93.

SVS, 2015. Informe Final-Fortalecimiento de Estandares de Gobierno Corporativo de las Sociedades Anonimas Chilenas. June 2015. 


\section{Appendix. Methodology, Data, and Additional Results}

\section{Regime-switching market liquidity}

\section{Non-linearities in the behavior of market liquidity are best captured by a} switching regression framework. Liquidity is modeled as a step function with two possible values: low and high. The behavior of market liquidity - when measured with the high-low spread measured - is characterized by the following Markov-switching process:

$$
L_{t}=\alpha_{i}+\varepsilon_{t} \text { if } s_{t}=i, \text { for } i=1 \text { or } i=2 \text {, }
$$

where the state variable $s_{t}$ determines the market liquidity regime ( 1 if low and 2 if high) and follows a simple switching process such that $\operatorname{Prob}\left(s_{t}=1\right)=p_{t}$ and $\operatorname{Prob}\left(s_{t}=2 \mid\right)=q_{t}$, for $\mathrm{t}=1, \ldots, \mathrm{N}$. The time-series behavior or market liquidity is then summarized by the one-step ahead forecast of the transition probabilities. These probabilities are then scaled using a logit transformation so that they are no longer bounded between one and zero. ${ }^{23}$ Specifically, the following transformation is applied to the one-month ahead probability of being in the low liquidity regime:

$$
P L I Q_{t} \equiv \log \left(\frac{\hat{p}_{t}+c}{1-\hat{p}_{t}+c}\right),
$$

where $c \equiv 0.5 / N$. In a final step, the probability of each liquidity regime is regressed on a set of observable factors, including global risk aversion, the U.S. monetary policy stance, and domestic macroeconomic conditions.

28. A linear regression framework captures the importance of external and domestic cyclical factors. The regression uses the transformed one-month ahead probability of aggregate stock market liquidity being in a low liquidity regime (PLIQ) as the dependent variable. The benchmark specification is as follows.

$$
P L I Q_{t}=\beta_{0}+\beta_{1} V I X_{t}+\beta_{2} F F_{t}+\beta_{3} A D S_{t}+\beta_{4} \Delta Y_{t}+\beta_{5} \operatorname{Infl}_{t}+\beta_{6} i_{t}+\gamma P L I Q_{t-1}+u_{t},
$$

where VIX is the S\&P500 implied volatility index from the Chicago Board Options Exchange, FF is the Federal Funds target rate, ADS is the Aruoba-Diebold-Scotti index of U.S. business conditions, PROD is the percent monthly change of the IMACEC economic activity index (chain linked), INFL is the percent monthly change in the consumer price inflation index for Chile, and IRATE is the Central Bank of Chile's monetary policy rate. The dependent variable, $P L I Q$, was tested for unit roots and turned out to be stationary, as expected.

\footnotetext{
${ }^{23}$ See IMF (2015) for details.
} 


\section{Cross-country determinants of market liquidity}

29. The impact of slow-moving country characteristics - such as investor protection - is estimated using a panel data regression for $\mathbf{2 3}$ emerging market economies. The regression includes country fixed effects and country-specific trends, and inference is conducted with country-level clustering. Market depth and volatility are lagged by one year to address potential endogeneity concerns. ${ }^{24}$ In order to include additional explanatory factors, benchmark econometric specification shown in (1) is expanded as follows:

$$
\begin{aligned}
& \text { Amihud }_{i t}=\alpha_{i}+\gamma_{i} t+\beta_{1} \text { VIX }_{t}+\beta_{2} \text { MarketDepth }_{i t-1}+\beta_{3} \text { Volatility }_{i t-1}+\beta_{4} \Delta G D P_{i t}+\beta_{5} \text { Inflation }_{i t} \\
& +\beta_{6} \text { PoliticalRisk }_{i t}+\beta_{7} \text { Shareholders }_{i t}+\beta_{8} \text { CrossHoldings }_{i t}+\varepsilon_{i t} \text {, } \\
& \text { Amihud }_{i t}=\alpha_{i}+\gamma_{i} t+\beta_{1} \text { VIX }_{t}+\beta_{2} \text { MarketDepth }_{i t-1}+\beta_{3} \text { Volatility }_{i t-1}+\beta_{4} \Delta G D P_{i t}+\beta_{5} \text { Inflation }_{i t} \\
& +\beta_{6} \text { PoliticalRisk }_{i t}+\beta_{7} \text { Shareholders }_{i t}+\beta_{8} I_{i t}+\varepsilon_{i t} \text {, } \\
& \text { Amihud }_{i t}=\alpha_{i}+\gamma_{i} t+\beta_{1} \text { VIX }_{t}+\beta_{2} \text { MarketDepth }_{i t-1}+\beta_{3} \text { Volatility }_{i t-1}+\beta_{4} \Delta G D P_{i t}+\beta_{5} \text { Inflation }_{i t} \\
& +\beta_{6} \text { PoliticalRisk }_{i t}+\beta_{7} \text { Shareholders }_{i t}+\beta_{8} \text { RuleLaw }_{i t}+\varepsilon_{i t} \text {, } \\
& \text { Amihud }_{i t}=\alpha_{i}+\gamma_{i} t+\beta_{1} \text { VIX }_{t}+\beta_{2} \text { MarketDepth }_{i t-1}+\beta_{3} \text { Volatility }_{i t-1}+\beta_{4} \Delta G D P_{i t}+\beta_{5} \text { Inflation }_{i t} \\
& +\beta_{6} \text { PoliticalRisk }_{i t}+\beta_{7} \text { Shareholders }_{i t}+\beta_{8} \text { Quality }_{i t}+\varepsilon_{i t} \text {, }
\end{aligned}
$$

where Amihud is Amihud's (2002) illiquidity measure, VIX is the Chicago Board of Trade implicit volatility index, MarketDepth is the country's stock market capitalization a percentage of GDP, Volatility is the standard deviation of daily equity returns over the year, PoliticalRisk is ICRG's annual political risk rating, Shareholders is the World Economic Forum's index of protection of minority shareholders, CrossHoldings is the average percentage of strategic holdings of at least five percent by one company in another (Thomson Reuters Datastream), $I O$ is the average ownership by institutional investors as a percent of the country's stock index market capitalization (FactSet), and RuleLaw and QualityR are the World Bank's indexes of rule of law and regulatory quality, respectively. The use of fixed effects controls for unobservable time-invariant characteristics that may be correlated with some of the explanatory variables but may be sensitive to a small number of influential observations. However, the results are robust to the iterated deletion of countries and years from the sample, to using Shareholders in logarithms, and to the winsorization of both Amihud and Shareholders.

\footnotetext{
${ }^{24}$ Lagging the investor protection variable, Shareholders, does not qualitatively change results.
} 


\begin{tabular}{|c|c|c|c|c|c|c|c|}
\hline \multicolumn{8}{|c|}{ Appendix Table 1. Descriptive Statistics for Emerging Market Panel Study } \\
\hline Variable & $\mathbf{N}$ & Average & $\begin{array}{l}\text { Standard } \\
\text { Deviation }\end{array}$ & Minimum & Median & $\begin{array}{c}\text { 75th } \\
\text { Percentile }\end{array}$ & Maximum \\
\hline Amihud's Illiqudity & 267 & 1.1 & 1.4 & 0.0 & 0.6 & 1.3 & 7.1 \\
\hline Market Capitalization & 267 & 65.2 & 48.0 & 8.7 & 49.5 & 83.6 & 283.4 \\
\hline Volatility & 267 & 3.1 & 5.8 & 0.4 & 1.5 & 2.1 & 45.0 \\
\hline$G D P$ & 267 & 9.1 & 2.6 & 5.2 & 8.8 & 10.6 & 16.2 \\
\hline Political Risk Rating & 267 & 68.1 & 8.1 & 47.0 & 68.0 & 75.5 & 83.5 \\
\hline Inflation & 267 & 4.9 & 4.7 & -24.2 & 4.4 & 7.0 & 23.0 \\
\hline GDP Growth & 267 & 4.4 & 4.2 & -11.3 & 4.8 & 6.3 & 26.2 \\
\hline Cross Holdings & 267 & 18.4 & 14.4 & 0.0 & 17.6 & 27.8 & 61.2 \\
\hline Institutional Ownership & 266 & 16.0 & 8.1 & 0.0 & 13.8 & 20.5 & 40.9 \\
\hline Protection of Minority Shareholders & 267 & 4.5 & 0.6 & 2.6 & 4.5 & 4.9 & 6.2 \\
\hline Rule of Law & 267 & 0.1 & 0.6 & -0.9 & 0.1 & 0.7 & 1.4 \\
\hline Regulatory Quality & 267 & 0.4 & 0.5 & -0.8 & 0.4 & 0.8 & 1.5 \\
\hline
\end{tabular}

\section{Stock liquidity and asset pricing in Chile}

30. The asset pricing implications of security-level liquidity in terms of the required rate of return for Chilean equity are captured using two variants of the standard FamaFrench empirical asset-pricing models. The study uses data from 220 ordinary stocks listed in Chilean exchanges (excluding ADR's) from January 1993 to March 2015. For each stock and using daily data, both the Amihud and the high-low spread measures of market illiquidity are calculated at monthly frequencies, and appropriately scaled. In addition, the study uses the monthly return of each stock in excess of the risk-free rate (the risk-free rate sourced from Kenneth French's website, adjusted for the monthly change in the Chilean peso's exchange rate relative to the dollar. ${ }^{25}$

\section{Since the applicable asset pricing model depends on the level of integration of} each market into the global financial market (see Errunza and Losq 1985, and Lee 2011 for a more recent discussion) the study estimates abnormal excess returns using two alternative empirical models. The first model assumes partial segmentation and includes the local market average excess return, the global market excess returns, and the SMB (size

\footnotetext{
${ }^{25}$ The assumption is that although the Chilean stock market may be partially segmented, investors can borrow or save at the global risk free rate in dollars. Using the Central Bank of Chile's monetary policy rate yields very similar results but restricts sample size.
} 
factor) and HML (growth factor) global portfolio excess returns sourced from Kenneth French's website. The second model assumes full international integration of the Chilean financial market and uses only the global factors. For each specification and month, abnormal returns are the estimated intercepts calculated by regressing the portfolio excess returns on the relevant factors using the previous five years of data. The specifications are as follows:

$$
\begin{aligned}
& r_{i t}=\alpha_{i}+\beta_{i}^{w} r_{t}^{w}+\beta_{i}^{H} H M L_{t}^{w}+\beta_{i}^{S} S M B_{t}^{w}+\varepsilon_{i t}, \text { and } \\
& r_{i t}=\alpha_{i}+\beta_{i}^{d} r_{t}^{d}+\beta_{i}^{w} r_{t}^{w}+\beta_{i}^{H} H M L_{t}^{w}+\beta_{i}^{S} S M B_{t}^{w}+\varepsilon_{i t},
\end{aligned}
$$

where $r_{i}$ is the excess return of portfolio $i, r^{w}$ is the excess return of the world market portfolio, $H M L$ is the return on the value versus growth portfolio, and $S M B$ is the return in the small firm versus large firm portfolio. Finally, $r^{d}$ is the aggregate excess return of the Chilean stock market. All excess returns are calculated relative to the three month U.S. Treasury bill return.

\section{The abnormal return associated with each portfolio is measure by the return which cannot be explained by observable portfolio factors (market, HML, and SMB} factors). Table 3 shows that the least liquid portfolio commands an additional monthly return of 0.14 percent, which is 0.4 percentage points higher than what is earned by the most liquid portfolio, if one assumes that the Chilean stock market is only partially integrated into global financial markets. However, because there may be (potentially unobservable) portfolio characteristics correlated with liquidity, the study cannot conclusively attribute the entirety of abnormal returns to market liquidity.

\section{Regardless of the assumption on market segmentation, estimates suggest the} abnormal return associated with illiquid stocks is substantial. The premium associated with stock liquidity is estimated by sorting stocks, every month, according to the previous six months liquidity level using the Amihud measure and aggregating them into four portfolios with increasing average liquidity. ${ }^{26}$ The aggregation of stocks into portfolios employs Asparahouva, Bessembinder, and Kalcheva's (2010) weights.

\footnotetext{
26 The high-low spread produces somewhat similar but noisier rankings. The relatively small number of portfolios (most studies use 10 portfolios; see Pastor and Stambaugh 2003, Lee 2011, and Corwin and Schulz 2012) is warranted by the study only having 220 shares available. When creating the portfolios, only stocks with at least 60 months of data are included.
} 